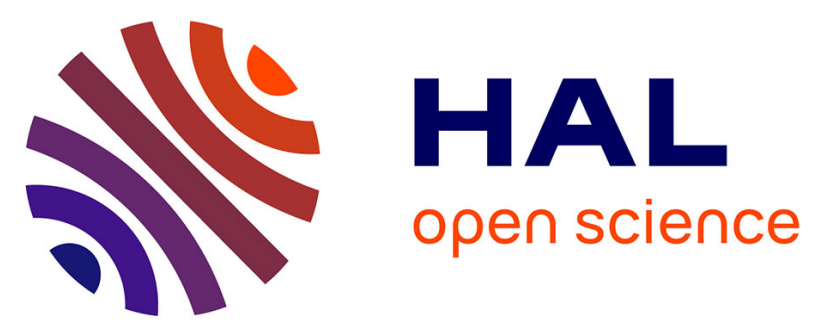

\title{
Screening for new mutations in the LDL receptor gene in seven French familial hypercholesterolemia families by the single strand conformation polymorphism method
}

\author{
N. Loux, B. Saint-Jore, Gwenaelle Collod, F. Dairou, P. Benlian, J. Truffert, \\ B. Dastugue, P. Douste-Blazy, J. L. de Gennes, C. Junien, et al.
}

\section{To cite this version:}

N. Loux, B. Saint-Jore, Gwenaelle Collod, F. Dairou, P. Benlian, et al.. Screening for new mutations in the LDL receptor gene in seven French familial hypercholesterolemia families by the single strand conformation polymorphism method. Human Mutation, 1992, 1 (4), pp.325 - 332. 10.1002/humu.1380010411. hal-01662653

\section{HAL Id: hal-01662653 https://hal.science/hal-01662653}

Submitted on 13 Dec 2017

HAL is a multi-disciplinary open access archive for the deposit and dissemination of scientific research documents, whether they are published or not. The documents may come from teaching and research institutions in France or abroad, or from public or private research centers.
L'archive ouverte pluridisciplinaire HAL, est destinée au dépôt et à la diffusion de documents scientifiques de niveau recherche, publiés ou non, émanant des établissements d'enseignement et de recherche français ou étrangers, des laboratoires publics ou privés. 


\title{
RESEARCH ARTICLE
}

\section{Screening for New Mutations in the LDL Receptor Gene in Seven French Familial Hypercholesterolemia Families by the Single Strand Conformation Polymorphism Method}

\author{
N. Loux, B. Saint-Jore, G. Collod, F. Dairou, P. Benlian, J. Truffert, B. Dastugue, P. Douste-Blazy, \\ J.L. de Gennes, C. Junien, ${ }^{*}$ and C. Boileau \\ INSERM U73, Château de Longchamp, 75016 Paris, France (N.L., B.S-J., G.C., P.B., C.J., C.B.), Service Endocrinologie, \\ CHU Pitié-Salpêtrière, 75013 Paris, France (F.D., P.B., J.T., J.L.dG.), CHR Clermont-Ferrand, 63100 Cebazat, France \\ (B.D.), and INSERM U101, CHU Purpan. 31059 Toulouse. France (P.D.B.)
}

Communicated by Michel Goussens

\begin{abstract}
To investigate the molecular basis of familial hypercholesterolemia $(\mathrm{FH})$ in France, we applied the single strand conformation polymorphism (SSCP) method to the promoter region and the 18 exons of the low density lipoprotein receptor (LDLR) gene. Seven probands, 4 heterozygotes, 2 compound heterozygotes, and 1 homozygote, belonging to $\mathrm{FH}$ families were tested. In all cases, previous genetic analysis and/or LDL receptor fibroblast assay had shown that the disease was due to defects in the LDLR gene. Out of the nine mutations expected, one nonsense mutation in exon 2 and six missense mutations were identified in exons $3,6,8,11$, and 15 . Two of the latter were found in exon 6 . In each family, cosegregation of the base substitution and the disease was observed. Ninety-five control subjects were screened for the presence of the six missense mutations. None was detected, implying that the mutations identified are deleterious. Our results indicate that the SSCP anaiysis of amplified genomic DNA fragments can be successfully used to rapidly screen mutation containing exons in large genes. Furthermore, all these mutations are newly described and demonstrate heterogeneity of LDLR gene mutations responsible for $\mathrm{FH}$ in the French population, as in other reported Caucasian populations. 1992 Wilev-Liss, Inc.
\end{abstract}

KEY wORDS: Familial hypercholesterolemia, LDL receptor, Single strand conformation polymorphism

\section{INTRODUCTION}

Familial hypercholesterolemia (FH) is a common autosomal dominant disorder that affects about one in 500 persons. FH is clinically characterized by an elevated plasma low density lipoprotein (LDL) concentration, tendon xanthomas, and an increased risk of coronary arterial disease (Goldstein and Brown, 1989).

More than 50 different mutations in the gene encoding the LDL receptor have now been reported at the molecular level in individuals with FH (for review see Hobbs et al., 1990; Benlian and Loux. 1991). These mutations, preventing normal clearance of plasma LDL (Goldstein and Brown, 1989), are spanned throughout the 45 kilobases (kb) of the LDL receptor gene (LDLR) located on chromosome 19p13 (Südhof et al., 1985). Twothirds of these mutations are gross gene rearrange- ments easily detected by Southern blot analysis. Since detection of point mutations is more difficult and relies on svstematic sequencing, their number is probably underestimated with only 16 described to date. To avoid sequencing of each of the 18 exons of the LDL receptor gene, it was necessary to develop methods to screen rapidly for unknown mutations in $\mathrm{FH}$ patients. These methods should enable localization of the gene defect, restricting sequencing to the targetted exons. A variety of methods have now been proposed (for review see Rossiter and Caskey, 1990), among them, the RNase A cleavage method (Myers et al., 1985) which tailed to detect about one third of possible single base substitutions, chemical cleavage (Cot-

Received May 12. 1992; accepted July 16, 1992.

"To whom repnnt requests/correspondence should be addressed.

¿ 1992 WILEY-LISS, INC. 
TABLE 1. Oligonucleotides for SSCP Analusis of 6 Exons and the promoter of the LDLR

\begin{tabular}{|c|c|c|}
\hline & $\begin{array}{l}\text { PCR primers }{ }^{\mathrm{a}} \\
\quad\left(5^{\prime} \rightarrow 3^{\prime}\right)\end{array}$ & $\begin{array}{c}\text { Size of } \\
\text { amplified product } \\
\text { (bp) } \\
\end{array}$ \\
\hline Promoter & $\begin{array}{l}\text { TCAGAGCTTCACGGGTTAAAAG } \\
\text { CCGCGATTGCACTCGGGGC }\end{array}$ & 166 \\
\hline Exon 4 & $\begin{array}{l}\text { CCCCCAAGACGTGCTCCCA } \\
\text { CGCAGTTTTCCTCGTCAGAT }\end{array}$ & 381 \\
\hline Exon 7 & $\begin{array}{l}\text { GGGACCAACGAATGCTTGGACAAC } \\
\text { AATCACCTTCGCATCTTCGCTGGG }\end{array}$ & 127 \\
\hline Exon 10 & $\begin{array}{l}\text { ACCCAGCTTGACAGAGCCCA } \\
\text { CCATGAACAGGATCCACCAC }\end{array}$ & 227 \\
\hline Exon 12 & $\begin{array}{l}\text { TTATCCACTTGTGTGTCTAGA } \\
\text { TTCGATCTCGTACGTAAGCCA }\end{array}$ & 184 \\
\hline Exon 16 & $\begin{array}{l}\text { TTCTCTCCTGCAGCTCTGGG } \\
\text { GCTTACCGATGGGGAGGACA }\end{array}$ & 97 \\
\hline Exon 17 & $\begin{array}{l}\text { TGCCTCTCCCTACAGTGCTC } \\
\text { ACTCACCGAGGGGTAGCTGT }\end{array}$ & 179 \\
\hline
\end{tabular}

afor each exon. the primer at the $5^{\prime}$ end is on the first line and that at the $3^{\prime}$ end is on the second line.

ton et al., 1988) or denaturing gradient gel electrophoresis (Sheffield et al., 1989) which seem to be more efficient methods but are not always simple and easy to use. Single strand conformation polymorphism (SSCP) (Orita et al., 1989) represents an efficient and technically simple method, but is limited to the study of 200 base pair (bp) fragments. With its short exons, the LDL receptor gene was thus particularly suited to the SSCP analysis. The technique involves the electrophoretic separation of single strands of DNA on a nondenaturing polyacrylamide gel. Under these conditions, electrophoretic mobility of a single strand DNA depends on its conformation, which is directly related to its nucleotide sequence. Therefore, any change in the sequence should theoretically generate a variant electrophoretic pattern.

In the present report we studied a sample of French $\mathrm{FH}$ patients, from which previous genetic data and fibroblast LDL receptor assay had linked the disease to the LDL receptor gene. Furthermore, no major gene arrangement had been found. For identification of point mutations lying anywhere within the coding region of the probands, we have used the SSCP method to systematically screen the promoter region and the 18 exons of the LDL receptor gene.

\section{PATIENTS AND METHODS}

\section{Patients}

Patients with severe hypercholesterolemia, tendon xanthomas in some cases, and a family history of high cholesterol levels and heart disease, were selected. A total of seven probands and members of their family, belonging to independent kindreds numbered 1 to 7 , were studied. The diagnosis of
FH was based on plasma cholesterol and LDL values in the patients. The four probands belonging to family $2,4,5$, and 7 were clinically considered as heterozygotes with plasma cholesterol levels over $300 \mathrm{mg} / \mathrm{dl}$, while the three probands belonging to family 1,3 , and 6 were clinically considered as homozygotes and had plasma cholesterol levels over $600 \mathrm{mg} / \mathrm{dl}$ before the age of ten with tendon and cutaneous xanthomas. In these subjects, analysis of the LDLR gene haplotypes revealed that two probands, belonging to family 3 and 6 , were in fact compound heterozygotes and had inherited a different mutant $L D L$ receptor allele from each parent. The remaining proband, from family 1 , was genetically homozygote with a family history of consanguinity. In all cases, previous genetic data or fibroblast LDL receptor assay had associated the disease to the LDLR gene.

\section{PCR-SSCP Analysis}

The PCR-amplified products of the promoter region and the 18 exons in the LDLR gene were studied with the SSCP method (Orita et al., 1989). The sequences of the primers that were specifically designed with the Oligotest program (Beroud et al., 1990) for this study are listed in Table 1. The other primers used were those described by Leitersdorf and co-workers (1990). PCR reactions were performed in a volume of $50 \mu \mathrm{l}$, using $0.5 \mu \mathrm{g}$ genomic DNA, $200 \mu \mathrm{mol}$ dNTPs, $1.25 \mathrm{IU}$ Taq polymerase, $0.25 \mu \mathrm{l}$ of $\left[\alpha-{ }^{32} \mathrm{P}\right] \mathrm{dCTP}$, and $0.25 \mu \mathrm{l}$ of $\left[\alpha{ }^{32} \mathrm{P}\right] \mathrm{dATP}$ in $10 \mathrm{mM}$ Tris- $\mathrm{HCL}$ $\mathrm{pH} 8.3,50 \mathrm{mM} \mathrm{KCl}, 1.5 \mathrm{mM} \mathrm{MgCl}_{2}, 0.01 \%$ gelatin; 10 pmol of each primer were used to amplify the majority of the exons. For exons 8 and 14, 5 pmol of primers was used. For exon $18,40 \mathrm{pmol}$ of 
TABLE 2. Mutation-Specific Oligonucleotide Probes

\begin{tabular}{llcc} 
Probe & \multicolumn{1}{c}{$\begin{array}{c}\text { Sequence } \\
\left(5^{\prime} \rightarrow 3^{\prime}\right)\end{array}$} & $\begin{array}{c}\text { Washing } \\
T_{\mathrm{m}}{ }^{\mathrm{a}}\end{array}$ & 60 \\
\hline $\begin{array}{l}\text { Glu-80 } \\
\text { Lys-80 }\end{array}$ & GGCTCAGACGAGCAAGGC & 58 & 62 \\
Asp-283 & GGCTCAGACAAGCAAGGC & 60 & 60 \\
Tyr-283 & GACTGCCGGGACTGGTCA & 50 \\
Lys-290 & GACTGCCGGTACTGGTCA & 58 & 54 \\
Arg-290 & GAACCCATCAAAGAGTGC & 54 & 58 \\
Cys-347 & GAACCCATCAGAGAGTGC & 56 & 68 \\
Tyr-347 & AGCCAGCTCTGCGTGAAC & 58 & 58 \\
Gly-528 & AGCCAGCTCTACGTGAAC & 56 & 58 \\
Val-528 & GGCCTGAATGGTGTGGAC & 58 & 56 \\
Thr-705 & GGCCTGAATGTTGGGAC & 56 & 60 \\
\hline$l y-705$ & GAGACATCCACCGTCAGG & 58 & 56 \\
\hline
\end{tabular}

Melting temperature.

primers was added to the reaction mixture. Amplification conditions were 30 cycles of $1 \mathrm{~min}$ denaturation at $94^{\circ} \mathrm{C}, 1 \mathrm{~min}$ annealing at $55^{\circ} \mathrm{C}, 1$ min 30 sec elongation at $73^{\circ} \mathrm{C}$, except for exons 6 , 9,10 , and 11 where annealing was at $62^{\circ} \mathrm{C}$, and exons 12,15 , and 16 where annealing was at 56 , 50 , and $65^{\circ} \mathrm{C}$, respectively. The labelled PCR fragments were diluted $1 / 10$ in a solution of $0.1 \%$ SDS, $10 \mathrm{mM}$ EDTA. An aliquot of $2 \mu \mathrm{l}$ was mixed with $2 \mu \mathrm{l}$ of $95 \%$ formamide, $20 \mathrm{mM}$ EDTA, $0.05 \%$ bromophenol blue, and $0.05 \%$ xylene cyanol, heated at $95^{\circ} \mathrm{C}$ for $2 \mathrm{~min}$, and put on ice. Samples of $4 \mu$ l were then loaded onto a 5 or $6 \%$ nondenaturing polvacrylamide gel with or without $10 \%$ glycerol. Electrophoresis was performed at room temperature at $5 \mathrm{~W}$ for $16 \mathrm{hr}$ for glycerol containing gels, and at $6 \mathrm{~W}$ for $7 \mathrm{hr}$ for gels without glycerol. The gel was dried onto $3 \mathrm{MM}$ paper and was autoradiographed at $-80^{\circ} \mathrm{C}$ for $20 \mathrm{hr}$.

\section{DNA Sequencing}

Exons displaying variant patterns were sequenced using the asymmetric PCR method (Attree et al., 1989). Following the first PCR reaction, a second amplification was carried out with an unequal ratio of primers (50:2) for 50 cycles, under conditions similar to those of the first PCR described above. To increase the specificity of the amplification, the first 10 cycles were performed with an increased annealing temperature corresponding to the $T_{m}$ of the primer in excess. Singlestrand PCR products were first purified and concentrated on a Centricon-100 microconcentrator (AMICON) according to the manufacturer's instructions, and subsequently sequenced by the Sanger dideoxy method (Sanger et al., 1977) (Se- quenase kit; version 2.0. USB) using $10 \mathrm{pmol}$ of the appropriate primer.

\section{Allele-Specific Oligonucleotide Hybridization}

Ninety-five control subjects were screened for the presence of the six missense mutations detected by SSCP in exons 3, 6 (two mutations), 8, 11 , and 15 , employing PCR-amplification followed by ASO hybridization. After $\mathrm{NaOH}$ denaturation, 3/50 vol of the PCR reaction was dotted onto a charge-modified nylon membrane (Gelman Science). ASO hybridization was performed under standard conditions (Saiki et al., 1986). The sequence of the primers used as probes specific for either the normal or the mutant sequence, and the appropriate washing conditions are described in Table 2.

\section{RESULTS}

The involvement of the $\mathrm{LDL}$ receptor gene was ascertained by haplotyping, or by assay of the receptor activity on tibroblasts, or by both. Haplotyping of the LDLR gene was performed by Southern blot experiments, in all probands, with an average of 6 RFLPs. Segregation of LDLR haplotypes with the disease was observed in families 1 , $2,4,5$, and 6 (data not shown). Haplotyping was also performed for the apo $B$ gene, excluding its implication in families $1,2,4$, and 5 . In the remaining families, the mutation at codon 3,500 in the apo B gene was not found (data not shown). Furthermore, by tibroblast assays less than $5 \%$ of the normal amount of LDL receptor activity was found in probands of family 1,2 , and 6 . In proband of family $7,50 \%$ of the normal amount of LDL receptor activity was measured (data not shown). 

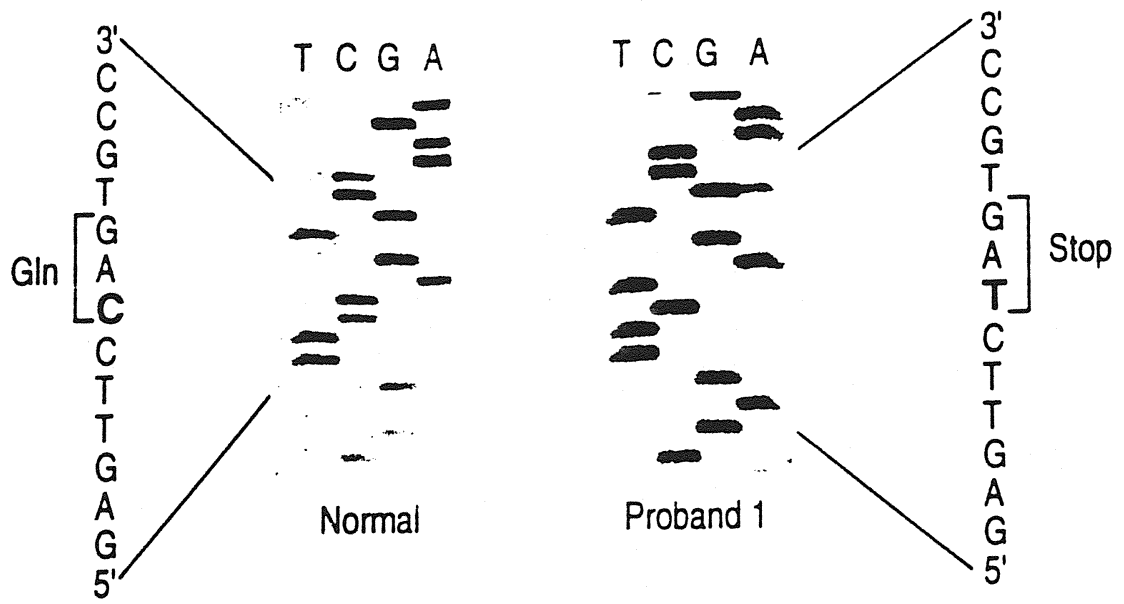

FIGURE 1. Comparison of LDLR exon 2 DNA sequence in the region surrounding codon 12 from a normal subject and proband 1 which presented an abnormal migration profile by SSCP analysis. The base substituted in the patient is indicated in bold and changes a Gln codon to a Stop codon.

In this study, the promoter region and the 18 exons of the LDLR gene were separately PCR amplified with primers which flank each exon sequence. Consecutively, each PCR product was analyzed with the SSCP method. Using this approach, we screened 7 unrelated $\mathrm{FH}$ patients for unknown LDLR mutations, and we identified abnormal electrophoretic patterns in six different exons, for six subjects. In the remaining patient, the migration patterns in all the exons tested were similar to those observed for controls. Optimal results were obtained with both glycerol containing gels and gels without glycerol, when electrophoresis was performed at room temperature. Sequence analysis of exons revealing variant patterns identified 7 base substitutions as yet unreported.

The proband of family 1 has a $C \rightarrow T$ substitution of ${ }^{12} \mathrm{Gln}(\mathrm{CAG})$, which creates a stop codon (TAG) in exon 2 and would cause a premature termination in LDL receptor synthesis. As shown in Figure 1, the proband was found to be homozygous for the nonsense mutation, and his parents were heterozygous for this mutation as expected from the family history of consanguinity.

The proband and two affected members of family 2, father and paternal uncle, were found to be heterozygous for a $G \rightarrow A$ transition that changes ${ }^{80} \mathrm{Glu}$ (GAG) to Lys (AAG) in exon 3 (data not shown).

The proband belonging to family 3 was found to be heterozygous for a $A \rightarrow G$ transition that substitutes ${ }^{290} \mathrm{Lys}$ (AAA) to $\operatorname{Arg}(\mathrm{AGA})$ in exon 6. This patient is a compound heterozygote and had inherited two different mutations from his parents.
Family 3
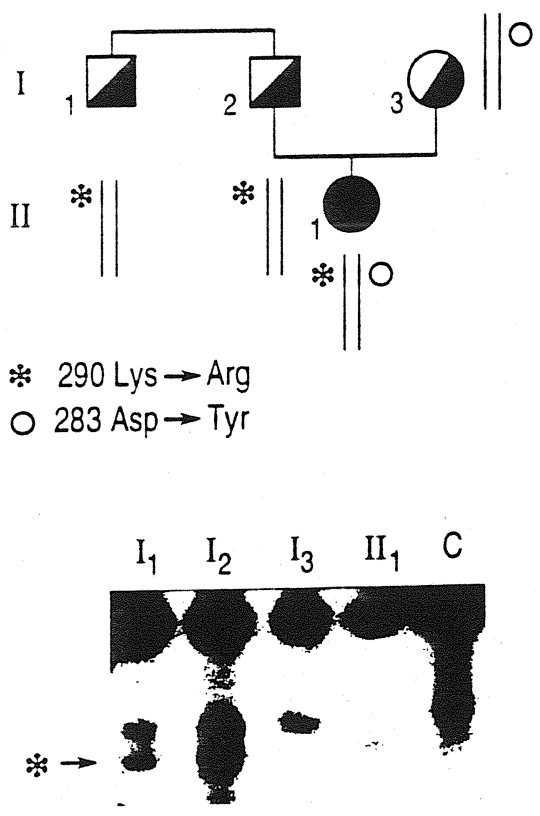

FIGURE 2. SSCP analysis of PCR fragment encompassing LDLR exon 6 in members of family 3. The abnormal frag. ment is indicated by an arrow and corresponds to the ${ }^{290}$ Lys $\rightarrow$ Arg mutation. This mutation is referred to by an asterisk $(*)$ and is present in affected members from the paternal side of the family. The ${ }^{283} \mathrm{Asp} \rightarrow$ Tyr mutation is referred to by $(\mathrm{O})$ and is present in affected members from the maternal side. This mutation is undetectable by SSCP analysis, since the mother $\left(I_{3}\right)$ has the same migration pattern as the control (C).

As shown in Figure 2, SSCP analysis identified abnormal electrophoretic patterns in affected individuals from the paternal side of the pedigree, fa- 

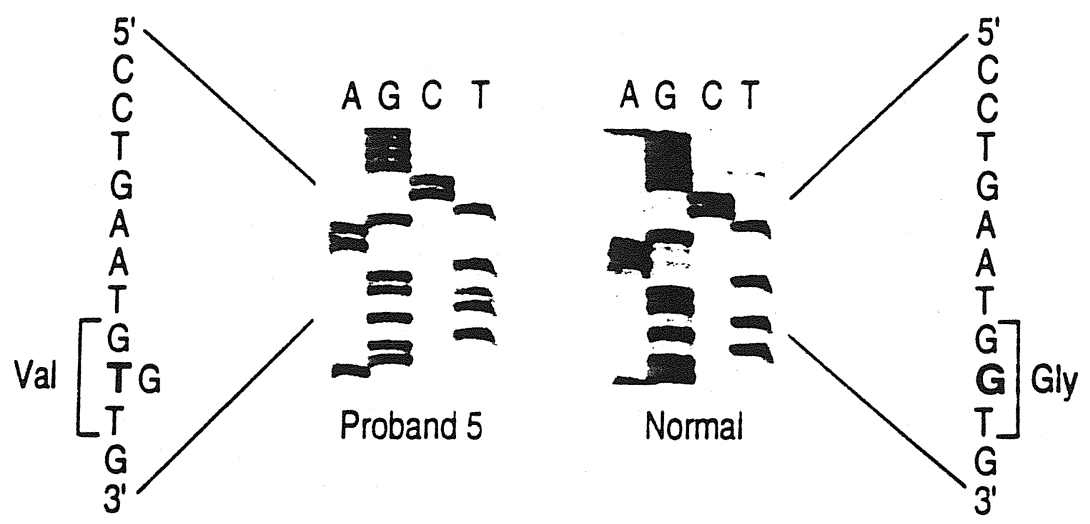

FIGURE 3. Sequence analysis of exon 11 from the proband belonging to family 5 presenting an abnormal migration pattern by SSCP procedure. Proband 5 is heterozygous for the ${ }^{528} \mathrm{Gly} \rightarrow$ Val mutation. The base substituted in the patient is indicated in bold.

ther and uncle, implying that the proband has inherited the ${ }^{290} \mathrm{Lys} \rightarrow$ Arg substitution from his father. The mutation on the maternal side was discovered by sequence analysis. Surprisingly, sequencing of exon 6 revealed the presence of a second nucleotide change, that did not alter the electrophoretic mobility by the SSCP method, since the mother showed a migration pattern similar to that of the control (Fig. 2). It constitutes a $G \rightarrow T$ transition that replaces ${ }^{283} \mathrm{Asp}$ (GAC) by Tyr (TAC). By sequence analysis, this mutation was found at the heterozvgous level in the proband as well as in affected members from the maternal side of the family, mother and aunt.

The proband of tamily 4 was found to be heterozvgous for a $G \rightarrow$ A change that substitutes ${ }^{347}$ Cys (TGC) to $\operatorname{Tyr}(T A C)$ in exon 8 . The abnormal SSCP pattern was present in the affected father and not in the healthy mother (data not shown).

The proband and affected members of family 5 , daughter, mother, maternal uncle, and maternal cousin, were found to be heterozygous for a $G \rightarrow T$ transition that changes ${ }^{528} \mathrm{Gly}$ (GGT) to $\mathrm{Val}$ (GTT). This mutation detected in exon 11 is shown in Figure 3.

The proband belonging to family 6 , who is expected to be a compound heterozvgote, has a $\mathrm{C} \rightarrow$ $\mathrm{T}$ substitution at the heterozygous level that changes ${ }^{705} \mathrm{Thr}$ (ACC) to lle (ATC) in exon 15. Inheritance of the mutation was tested in tamilv members: the sister and the tather, both $\mathrm{FH}$ patients, were shown to be heterozvgous for the mutation as analysed by SSCP (Fig. 4). The mutation in the LDLR gene transmitted by the mother remains undetected.

In all tamilies, inheritance of the mutation(s)
Family 6

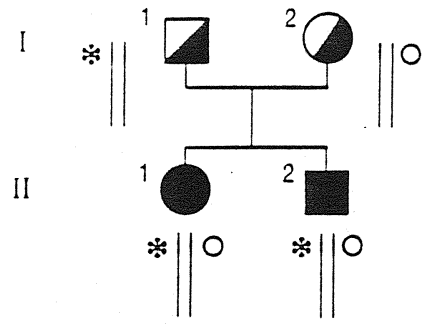

$\because 705 \mathrm{Thr} \rightarrow$ Ile

O mutation not detected

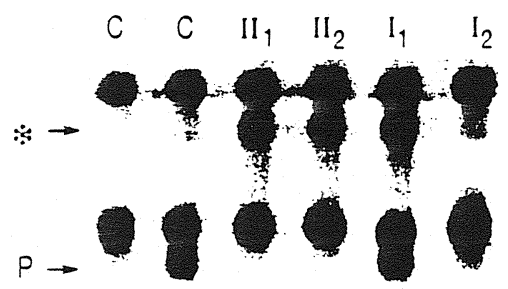

FIGURE 4. SSCP analusis of LDLR exon 15 in members of family 6 . The abnormal fragment corresponding to the ${ }^{705} \mathrm{Thr} \rightarrow$ Ile mutation is indicated by an asterisk $(*)$. This mutation is present in affected members from the paternal side of the family. The second abnormal band corresponding to a sequence polumorphism is indicated by $(P)$, and is present both in the control $(C)$ and the affected subject $\left(I_{1}\right)$.

was analvsed either by SSCP and/or sequence anal$y$ sis, and was found to be associated with the $\mathrm{FH}$ phenotvpe. However, in order to further determine if the missense mutations were diseasecausing mutations or polymorphisms segregating with the disease, we examined 95 control individuals by ASO hrbridization. We identified none of 
TABLE 3. List of the LDLR Mutations Identified in the Probands.

\begin{tabular}{llll}
\hline $\begin{array}{l}\text { Proband } \\
\text { number }\end{array}$ & FH phenotype & Genetic status & Mutations \\
\hline 1 & Homozygote & Homozygote & ${ }^{12} \mathrm{Gln} \rightarrow$ Stop \\
2 & Heterozygote & Heterozygote & ${ }^{80} \mathrm{Glu} \rightarrow$ Lys \\
3 & Homozygote & $\begin{array}{l}\text { Compound } \\
\text { heterozygote }\end{array}$ & ${ }^{283} \mathrm{Asp} \rightarrow \mathrm{Tyr}$ \\
& ${ }^{290} \mathrm{Lys} \rightarrow$ Arg \\
4 & Heterozygote & Heterozygote & ${ }^{347} \mathrm{Cys} \rightarrow \mathrm{Tyr}$ \\
5 & Heterozygote & Heterozygote & ${ }^{528} \mathrm{Gly} \rightarrow$ Val \\
6 & Homozygote & Compound & ${ }^{705} \mathrm{Thr} \rightarrow \mathrm{Ile}$ \\
& & Heterozygote & \\
\hline
\end{tabular}

aEach proband is identified according to the family number: for exampie, proband 1 belongs to family 1 .

'The second mutation was not identified.

the six missense mutations in control subjects (data not shown). The 7 base substitutions identified in this study are listed in Table 3, their localisation with respect to the LDLR gene and protein are shown in figure 5 .

In some cases, variant electrophoretic patterns were found both in controls and $\mathrm{FH}$ individuals. Sequence analysis identified single base substitutions that did not change amino acids, implying they were polymorphisms. Two polymorphisms detected respectively in exons 2 and 18 were recently reported (Soutar, 1991; Cavanaugh and Esteal, 1991). The new polymorphisms observed in exons 10, 11, and 15 are described elsewhere (Saint-Jore et al., submitted).

\section{DISCUSSION}

In order to identify $\mathrm{FH}$ mutations in a French population, we have performed the SSCP technique to screen the promoter region and the 18 exons of the LDLR gene in probands, restricting sequencing to the exons revealing variant patterns. All patients whose migration profile was abnormal were found to carry a nucleotide change in the corresponding exon. However, in one patient the SSCP method failed to detect a mutation which was identified solely by sequencing: the ${ }^{283} \mathrm{Asp} \rightarrow$ Tyr substitution carried by proband 3 and his mother did not alter the electrophoretic pattern of exon 6. However the ${ }^{290}$ Lys $\rightarrow$ Arg substitution carried by proband 3 and his father altered the electrophoretic mobility of exon 6 (Fig. 2). This clearly shows that some nucleotide changes do not alter the electrophoretic mobility of amplified exons. In principle, after SSCP analysis, in a subject heterozygous for a mutation, the nucleotide substitution should generate two supplementary bands corresponding to the mutated DNA strand and its complementary mutated strand. Actually, in the majority of the heterozygotes, we observed only one additional band. On the other hand, in some cases SSCP analysis can discriminate one change from another simultaneously present in the same amplified exon product. For example, substitutions found in exon 15 , one mutation and one polymorphism, generate distinctly different migration profiles when analyzed by SSCP (Fig. 4). Thus, the ability of a single base substitution to alter the conformation of the DNA single strand is unpredictable and represents a drawback of this method.

In our study, six mutations out of the nine expected gave abnormal migration patterns after SSCP analysis. Therefore, one-third of the possible mutations were undetected by SSCP analysis. This failure to detect an abnormal pattern was only contirmed in one case, the ${ }^{283}$ Asp $\rightarrow$ Tyr mutation in exon 6. For the two other expected mutations, since only the exons and the promoter of the LDLR gene were investigated, it can also be proposed that the two remaining undetected mutations lie elsewhere within the gene. Although numerous methods have been designed to detect single base substitutions in PCR products, none of them is both technically simple and powerful enough to detect $100 \%$ of the possible mutations. Thus, coupling of these scanning methods should increase the probability of detecting mutations. Two methods have been reported recently that are technically simple to use. One is derived from SSCP, the rSSCP method which uses RNA instead of DNA (Danenberg et al., 1992; Sarkar et al., 1992). The other, the heteroduplex method, can complement the SSCP analysis because its principle does not rely on secondary structure formation (White et al., 1992).

In this study, we identified one nonsense mutation and six missense mutations. The nonsense mutation identified in codon 12 gives rise to a premature stop codon which eliminates almost all of the LDL receptor domains. This strongly suggests that the ${ }^{12} \mathrm{Gln} \rightarrow$ Stop change leads to a variant which fails to produce any $\mathrm{LDL}$ receptor protein. For the six missense mutations detected, the fact that we have not found these nucleotide changes in 95 control individuals, together with the segregation of these mutations with the $\mathrm{FH}$ phenotype in affected families, supports the hypothesis that these novel mutations are the cause of the disease. Furthermore, these variations affect amino acids that lie in domains important for maturation and function of the LDL receptor protein (Fig. 5). 


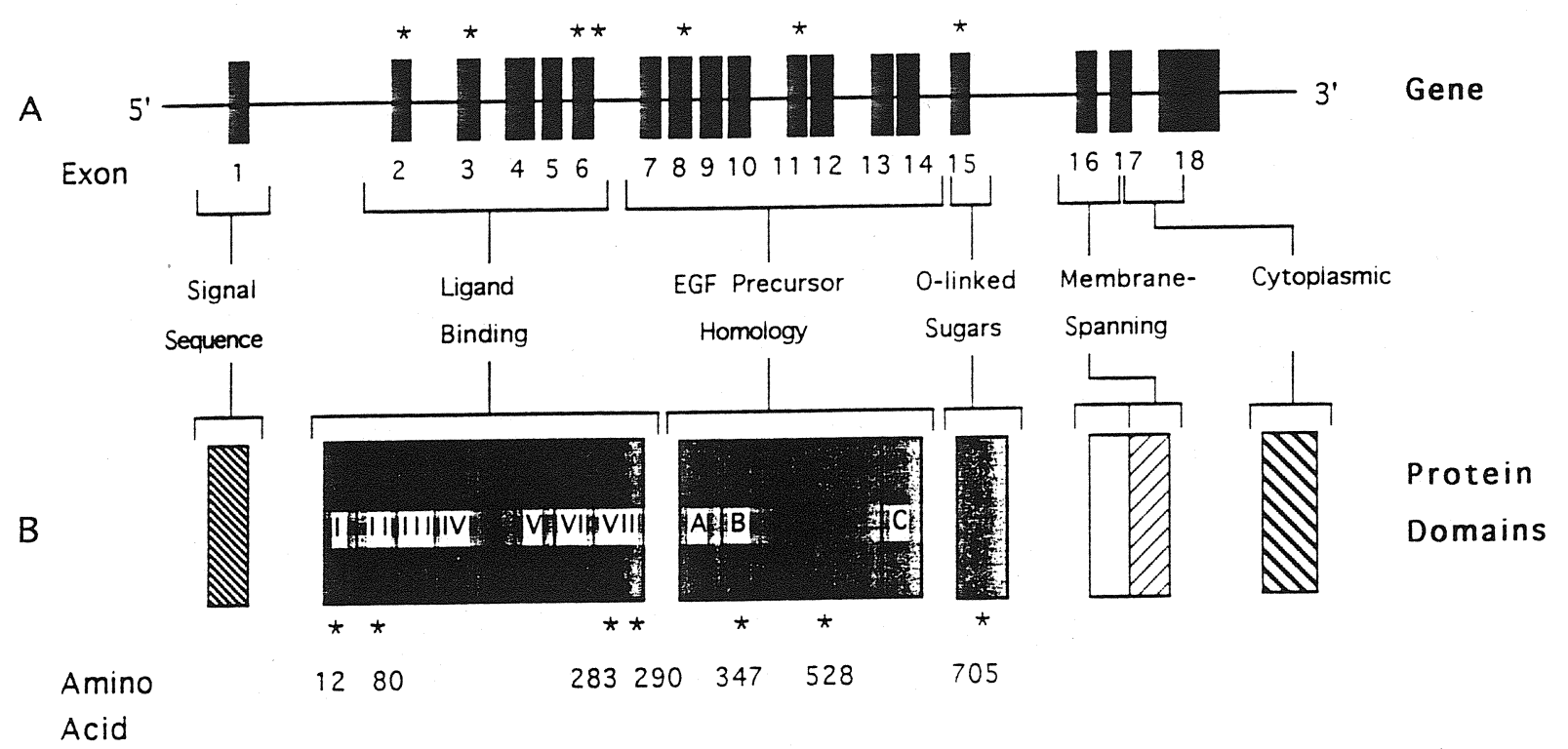

FIGURE 5. Schematic localisation of the mutations identified. Asterisks indicate their localisation in the LDLR gene $(A)$ and in the functional domains of the LDL receptor $(B)$.

Three missense mutations, the ${ }^{80} \mathrm{Glu} \rightarrow$ Lys, ${ }^{283} \mathrm{Asp} \rightarrow \mathrm{Tyr}$, and ${ }^{290} \mathrm{Lys} \rightarrow$ Arg substitutions, have been found in the ligand binding domain of the LDL receptor, which is composed of seven cysteine-rich repeats. Each repeat contains clustered negative charges that are involved in the binding of positively charged residues on apo B100 and apo E. The ${ }^{80} \mathrm{Glu} \rightarrow$ Lys and ${ }^{283} \mathrm{Asp} \rightarrow$ Tyr substitutions concerned amino acids that are highly conserved among animal species and among repeat sequences (Esser et al., 1988), and are involved in the clustering of negative charges. These mutations result in a change of a basic for an acidic amino acid in the second and the seventh repeat, respectively. Although these substitutions are expected to affect the binding of the LDL receptor to its ligand, previous studies have demonstrated that amino acid substitutions in conserved domains of cysteine-rich repeats alter the transport of the LDL receptor protein from the endoplasmic reticulum (ER) to the Golgi complex (Leitersdorf et al., 1988, 1990). These mutations seem to interfere with the normal folding of the protein and prevent the transport of the unproperly folded protein out of the ER. The same substitution of a lysine for a glutamic acid residue identified in the highly conserve negatively charged amino acids near the $\mathrm{COOH}$ terminus of the second repeat was previously observed in the same sequence but in the fifth repeat (Leitersdorf et al., 1990). The resulting protein was not transported normally out of the
ER. Since the nature and the number of amino acids located between cysteines are important for the proper folding of the protein, it can be proposed that the ${ }^{290} \mathrm{Lys} \rightarrow$ Arg substitution found near the last cysteine of the seventh repeat, interferes with the normal folding of the LDL receptor protein. Indeed steric hindrance of arginine is greater than that of lysine.

The missense mutation found in codon 347 is located in the epidermal growth factor (EGF) like domain, which contains 3 cysteine-rich repeats (A, B, and C). Each repeat contains 6 cysteines that are normally involved in the formation of disulfide bonds. The mutation located in repeat $B$ substitutes a tyrosine for a cysteine, giving rise to an unpaired cysteine. Another missense mutation, previously reported, results in the same substitution of a tyrosine for a cysteine but in repeat $\mathrm{C}$ (Leitersdorf et al., 1990). The effect of this mutation is to block the transport of the protein to the cell surface. Similarly, it can be proposed that the loss of a cysteine mav alter the proper folding of the LDL receptor protein, and thus prevent the transport of the protein out of the ER. The other mutation found in the EGF like domain that causes a substitution of a valine for a glycine at residue 528 does not reside in a cystein-rich region. However, the resulting LDL receptor protein may not be transported to the cell surface as an identical substitution of a valine for a glycine previously reported at residue 544 (Esser and Russel, 1988). 
These authors demonstrated that this substitution gave rise to a protein that is not transported out of the $R E$, and rapidly degraded.

The last missense mutation was identified in exon 15, which encodes the O-linked sugar domain. This mutation results in the change of an isoleucine for a threonine which is involved in the attachment of O-linked carbohydrate chains. The function of these O-linked sugars remains unknown. Divergent results have been reported concerning this domain. Davis and colleagues (1987) reported the construction of a cDNA with an exon 15 deletion which had no effect on receptor function in transfected fibroblasts, whereas Kajinami and co-workers (1988) described an exon 15 deletion found in an $\mathrm{FH}$ patient. The mutation reported in the present study is the first point mutation identified in this domain.

In conclusion, the work reported here demonstrates the usefullness of the SSCP method, applied to the detection of point mutations in the LDLR gene. Furthermore, the wide distribution throughout the gene and the heterogeneity of the base substitutions identified in this French population are in agreement with previous results reported in other Caucasian populations (Benlian and Loux, 1991; Russel et al., 1989).

\section{ACKNOWLEDGMENTS}

We wish to thank Dr. M. Brown, Dr. J. Goldstein, and Dr. B. Jacotot for providing the results of fibroblast LDL receptor assay of the probands. This work was supported by grants from Caisse $\mathrm{Na}$ tionale d'Assurance Maladie des Travailleurs Salariés. Fédération de Cardiologie, and Association Française contre les Myopathies.

\section{REFERENCES}

Attree O. Vidaud D. Vidaud M, Amselem S. Levergne IM, Goossens $M$ (1989) Mutations in the catalvtic domain of human coagulation factor IX: Rapid characterization by direct genomic sequencing of DNA fragments displaving an altered melting behaviour. Genomics 4:266-272.

Benlian P. Loux N (1991) LDL receptor gene mutations heter()geneity in familial hypercholesterolemia. M/S 7:1052-1060.

Beroud C. Antignac C, Jeanpierre C, Junien C (1990) A computer program for research of optimal primers tor PCR. M/S 6:901903.

Cavanaugh JA, Easteal S (1991) A Haell polvmorphism in the 3' untranslated region of the low density lipoprotein receptor (LDLR) gene. Nucl Acids Res 19:6663.

Cotton RGH, Rodrigues NR, Camphell DR (1988) Reactivity of crtosine and thymine in single-base-pair mismatches with hvdroxvlamine and osmium tetroxide and its application to the studv of mutations. Proc Natl Acad Sci USA 85:4397-4401.

Danenberg PV, Horikoshi T, Volkenandt M. Danenberg $K$. Lenz HI, Shea LCC, Dicker AP, Simoneau A. Jones PA, Bertino IR (1992) Detection of point mutations in human DNA by anal-
Isis of RNA contormation polymorphism(s). Nucl Acids Res 20:573-579.

Davis CG. Elhammer A. Russel DW, Schneider WJ, Kornfeld S, Brown MS. Goldstein IL (1986) Deletion of clustered O-linked carbohydrates does not impair function of low density lipoprotein receptor in transtected fibroblasts. J Biol Chem 261:28282838.

Esser V. Russel DW (1988) Transport-deficient mutations in the low density lipoprotein receptor. J Biol Chem 263: 13276-13281.

Esser V, Limbrid LE, Brown MS, Goldstein IL, Russel DW (1988) Mutational analvsis of the ligand binding domain of the low density lipoprotein receptor. J Biol Chem 263:13282-13290.

Goldstein JL, Brown MS (1989) Familial hypercholesterolemia In Scriver CR, Beaudet AL. Sly WS, Valle D (eds): The Metabolic Basis of Inherited Disease, 6th ed. New York: McGrawHill, pp 1215-1250.

Hobbs HH, Russel DW, Brown MS, Goldstein JL (1990) The LDL receptor locus in tamilial hypercholesterolemia: Mutational analysis of a membrane protein. Ann Rev Genet 24:133-170.

Kajinami K. Mabuchi H. Itoh H. Michishita I, Takeda M, Wakasugi T. Koizumi J, Takeda $R$ (1988) New variant of low density lipoprotein receptor gene: FH-Tonami. Arteriosclerosis 8:187192.

Leitersdorf E, Hobbs HH, Fourie AM, Jacobs M, Van Der Westhuvzen DR, Coetzee GA (1988) Deletion in the first cysteinerich repeat of low density lipoprotein receptor impairs its transport but not lipoprotein binding in fibroblasts from a subject with familial hypercholesterolemia. Proc Natl Acad Sci 85: 7912-7916.

Leitersdorf E. Tobin EJ, Davignon J, Hobbs HH (1990) Common low-density lipoprotein receptor mutations in the French $\mathrm{Ca}$ nadian population. J Clin Invest 85:1014-1023.

Mvers RM, Larin Z, Maniatis T (1985) Detection of single base substitutions by ribonuclease cleavage at mismatches in RNA: DNA duplexes. Science 230:1242-1246.

Orita M. Suzuki Y. Sekiva T, Havashi K (1989) Rapid and sensitive detection of point mutations and DNA polvmorphisms using the polvmerase chain reaction. Genomics 5:874-879.

Russel DW, Esser V, Hobbs HH (1989) Molecular basis of familial hypercholesterolemia. Arteriosclerosis 9 suppl. 1:8-13.

Rossiter BJF, Caskey CT (1990) Molecular scanning methods of mutation detection. J Biol Chem 265:12753-12756.

Saiki RK. Bugawan TL. Horn GT, Mullis KB, Erlich MA (1986) Analvsis of enzumatically amplified globin and HLA-DQ DNA with allele-specitic oligonucleotide probes. Nature (London) 324:163-166.

Sanger F. Nicklen S. Colvson AR (1977) DNA sequencing with chain-terminating inhibitors. Proc Natl Acad Sci USA 74: 5463-5467.

Sarkar G, Yoon HS. Sommer SS (1992) Screening for mutations hy RNA single-strand conformation polymorphism (rSSCP): comparison with DNA-SSCP. Nucl Acids Res 20:871-878.

Sheftield V, Cox DR, Lerman LS, Myers RM (1989) Attachment of a 40-base-pair $G+C$-rich sequence (GC-clamp) to genomic DNA fragments by the polymerase chain reaction results in improved detection of single-base-changes. Proc Natl Acad Sci USA 86:232-236.

Soutar AK (1991) A polvmorphism in exon 2 of the human LDL. receptor gene (LDLR). Nucl Acids Res 19:4314.

Südhot TC, Goldstein JL, Brown MS, Russel DW (1985) The LDL receptor gene: $A$ mosaic of exons shared with different proteins. Science 228:815-822.

White MB, Carvalho M, Derse D, O'Brien SJ, Dean M (1992) Detecting single base substitutions as heteroduplex polymorphisms. Genomics 12:301-306. 